\title{
ANALISIS KETERAMPILAN PROSES SAINS PADA PEMBELAJARAN BERBASIS PRAKTIKUM
}

\author{
Agil Lepiyanto \\ Pendidikan Biologi FKIP Universitas Muhammadiyah Metro \\ E-mail: Lepi22evolusi@gmail.com
}

\begin{abstract}
Learning should be able to develop the skills of students. One of the skills that can be developed is the science process skills. This study aims to determine how the science process skills that exist in practical based learning. This study is a qualitative research and using descriptive analysis. The results showed that in the course of learning lab plant morphology was found that the emerging science process skills are to observe, communicate and ask questions, while the process in the form of interpreting skills, reasoning, and grading (classification) does not appear.
\end{abstract}

Kata Kunci: practical based learning, science process skills

Tuntutan dan tantangan yang ada pada abad 21 berdampak adanya perubahan dalam pola pembelajaran yang ada dalam pendidikan di Indonesia. Pendidikan harus dapat mengembangakan sumber daya manusia yang kompeten yang memiliki daya saing. Tantangan tersebut harus dijawab oleh semua LPTK yang ada di Indonesia untuk menghasilkan calon-calon guru yang dapat mengembangkan pendidikan sesuai tuntutan abad 21. Guru saat ini harus dapat mengembangkan pembelajaran yang tidak berorientasi pada aktivitas menghafal. Guru harus memiliki kemampuan untuk berinovasi dalam mengembangkan pembelajaran sesuai kebutuhan abad 21. NSTA (2003) dalam wilujeng (2012) menetapkan 10 standar bagi persiapan guru IPA, meliputi standar isi (content), hakikat IPA (nature of science), inkuiri (inquiry), isu-isu IPA (issues), keterampilan umum mengajar (general skills of teaching), kurikulum (curriculum), komunitas IPA (science in the community), penilaian (assesment), keselamatan dan kesejahteraan (safety and welfare), serta pengembangan profesional (professional growth).

Salah satu keterampilan yang dapat dikembangkan untuk mempersiapkan guru abad 21 adalah keterampilan proses sains. Toharudin, hendrawati dan Rustaman (2014) keterampilan sains adalah keterampilan yang dapat digunakan untuk memahami fenomena apa saja yang terjadi. Keterampilan ini diperlukan untuk memperoleh, mengembangkan dan menerapkan konsep, prinsip dan hukun yang ada pada sains. Rustaman (2005:95) mendefinisikan keterampilan proses sains merupakan keterampilan yang diperlukan untuk memperoleh, mengembangkan dan menerapkan konsep-konsep, prinsipprinsip, hukum-hukum, dan teori sains, baik berupa keterampilan mental, keterampilan fisik (manual) maupun keterampilan sosial.Usman Samatowa (2006:137) mengemukakan bahwa keterampilan proses sains merupakan keterampilan intelektual yang dimiliki dan digunakan oleh para ilmuwan dalam meneliti fenomena alam. 
Dimyati dan Mudjiono (2002:140) menjelaskan bahwa berbagai keterampilan dalam keterampilan proses terdiri dari keterampilan-keterampilan dasar dan keterampilan terintegrasi. Keterampilan dasar terdiri dari enam keterampilan, yaitu: mengobservasi, mengk lasifikasi, memprediksi, mengukur, menyimpulkan, dan mengkomunikasikan. Keterampilan terintergrasi terdiri dari: mengidentifikasi variabel, membuat tabulasi data, menyajikan data dalam bentuk grafik, menggambarkan hubungan antar variabel, mengumpulkan dan mengolah data, menganalisis penelitian, menyusun hipotesis, mendefinisikan variabel secara operasional, merancang penelitian atau eksperimen.

\section{Donna}

mengemukakan

(1994:241)

bahwa:
Keterampilan proses Sains adalah teknik yang digunakan oleh ilmuwan dalam memperoleh informasi. Pada dasarnya, ini adalah keterampilan dan teknik yang ilmuwan di laboratorium untuk menemukan informasi baru tentang dunia. Keterampilan proses sains adalah teknik bahwa anak-anak yang menggunakan dalam mendapatkan informasi secara pengalaman pertama dari aktivitas atau kegiatan belajar siswa. Salah satu bentuk pembelajaran yang dapat memebrikan pengalaman belajar adalah kegiatan praktikum. Salah satu matakuliah yang pembelajarannya berorientasi kepada praktikum adalah morfologi tumbuhan. Kajian yang dilakukan pada matakuliah ini berkaitan struktur mahasiswa. Mahasiswa dilatih untuk mengidentifikasi struktur morfologi dari berbagai bagian tumbuhan. Oleh karena itu perlu dikaji tentang bagaimana keterampilan proses sains yang ada pada pembelajaran praktikum pada matakuliah morfologi tumbuhan. Hasil yang diperoleh nantinya akan menjadi dasar untuk pengembangan pembelajaran pada matakuliah morfologi tumbuhan.

\section{METODE}

Penelitian ini merupakan penelitian kualitatif. Penelitian dilakukan di program studi pendidikan biologi, Universitas Muhammadiyah metro pada tahun 2013. Subyek penelitian terdiri atas 78 mahasiswa yang menempuh matakuliah Morfologi Tumbuhan. Instrumen yang digunakan menggunakan lembar observasi keterampilan proses sains. Analisis data menggunakan analisis deskriptif.

\section{HASIL DAN PEMBAHASAN}

Prilianti (2014) Ilmu Pengetahuan Alam didefinisikan sebagai pengetahuan yang diperoleh melalui pengumpulan data dengan eksperimen, pengamatan, dan deduksi untuk menghasilkan suatu penjelasan tentang sebuah gejala yang dapat dipercaya. Penerapan pendekatan saintifik dalam pembelajaran melibatkan keterampilan proses seperti mengamati, mengklasifikasi, mengukur, meramalkan, menjelaskan, dan menyimpulkan. Pembelajaran IPA lebih menekankan pada penerapan keterampilan proses. 
Hasil observasi keterampilan proses sains yang didapatkan selama kegiatan praktikum morfologi tumbuhan

Tabel 1. Hasil observasi keterampilan proses sains

\begin{tabular}{|c|l|l|}
\hline No & Indikator KPS & $\%$ \\
\hline 1 & Mengamati (observasi) & 80 \\
\hline 2 & $\begin{array}{l}\text { Mengkomunikasikan } \\
\text { data }\end{array}$ & 60 \\
\hline 3 & $\begin{array}{l}\text { Menggolongkan } \\
\text { (klasifikasi) }\end{array}$ & - \\
\hline 4 & Menafsirkan data & - \\
\hline 5 & Meramalkan & - \\
\hline 6 & $\begin{array}{l}\text { Mengajukan } \\
\text { pertanyaan }\end{array}$ & 80 \\
\hline
\end{tabular}

Pembelajaran

pada

matakuliah morfologi tumbuhan pada program studi pendidikan biologi UM Metro telah melaksanakan kegiatan kegiatan praktikum. Praktikum yang dilakukan terdiri atas materi morfologi pada daun, batang, akar, bunga dan biji.

Tabel 1 terlihat bahwa keterampilan proses sains pada praktikum morfologi tumbuhan yang tampak adalah mengamati, mengkomunikasikan dan mengajukan pertanyaan. Keterampilan proses sains yang paling tinggi persentasenya adalah mengamati dan mengajukan pertanyaan. Indikator mengamati (observasi) yaitu tampak pada saat mahasiswa mengamati untuk mengumpulkan data tentang pengamatan morfologi tumbuhan. Mahasiswa melakukan pengamatan untuk menemukan fakta yang terkait dengan materi pembelajaran. Sebagai contoh mahasiswa mengamati struktur morfologi dari daun, mahasiswa harus menemukan bagaimana bentuk ujung daun, bangun daun, tepi daun, permukaan daun, pangkal daun dan warna dari daun yang dibawa pada saat praktikum. Aktivitas mengamati dapat memberikan pembelajaran lebih bermakna, karena mahasiswa mengamati fenomena yang ada di lingkungan. Toharudin, hendrawati dan Rustaman (2014) kegiatan oberservasi bermanfaat untuk pemenuhan rasa ingin tahu.

Munculnya rasa ingin tahun ini menimbulkan munculnya indikator keteramilan proses sains berupa mengajukan pertanyaan. Aktivitas ini tampak ketika mahasiswa mengajukan pertanyaan pada saat melakukan pengamatan, mahasiswa saling bertanya tentang apa saja yang mereka temukan pada saat aktivitas pengamatan, atau ketika mahasiswa mengalami kesulitan terkait tentang pemahaman materi. Aktivitas bertanya ini dilakukan sesama mahasiswa, asisten atau dosen. Adanya aktivitas bertanya maka mahasiswa dapat saling bertukar pengetahuan dan pemahaman terkait dengan materi. Pembelajaran dalam praktikum ini, mahasiswa diberikan kebebasan untuk mengajukan pertanyaan terkait apa yang mahasiswa telah laksanakan. Hasil analisis dari pertanyaan yang dilakukan oleh mahasiswa ditemukan bahwa tipe pertanyaan yang dikemukakan baru tipe kognitif yang rendah yaitu level pengetahuan, contoh pertanyaan yang dikemukakan oleh mahasiswa adalah apa yang dimaksud daun lengkap, sebutkan contoh lain daun majemuk. Temuan ini tentu saja perlu diatasi dengan memilih metode pembelajaran yang dapat membiasakan mahasiswa untuk berpikir lebih tinggi.

Indikator keterampilan proses sains berikutnya yang muncul pada praktikum morfologi tumbuhan 
adalah mengkomunikasikan data. Kegiatan mengkomunikasikan hasil observasi yang dilakukan berupa mahasiswa mengemukakan hasil pengamatan ke dalam berbagai bentuk seperti: gambar, bagan dan tulisan. Mahasiswa menganalisis hasil pengamatan kedalam gambar kemudian memberikan beberapa keterangan sesuai dengan tujuan yang ingin dicapai pada kegiatan praktikum morfologi tumbuhan. Contoh mahasiswa menggambar morfologi bagian-bagian bunga lengkap serta bagian-bagian tumbuhan lain yang telah didapatkan pada saat kegiatan pengamatan. Aktivitas lain yang memperlihatkan indikator mengkomunikasikan hasil observasi adalah mahasiswa mampu menjelaskan apa yang mereka amati kepada teman yang lain. Aktivitas ini juga menimbulkan potensi untuk mahasiswa mengajukan berbagai pertanyaan ketika hasil pengamatan yang mereka temukan tidak sama.

Ketidakmunculan indikator keterampilan proses berupa indikator menggolongkan (klasifikasi) menafsirkan data, dan meramalkan dikarenakan kegiatan pembelajaran praktikum pada matakuliah morfologi tumbuhan belum berorientasi pada pembelajaran yang berorentasi pada pendekatan ilmiah. Herawan (2007), dalam proses pembelajaran biologi, siswa tidak hanya mendengar, mencatat, dan menghafal informasi yang disampaikan guru, melainkan adanya kesempatan untuk memanipulasi dan memproses informasi. Temuan ini tentu saja harus diperbaiki untuk meningkatkan kompetensi mahasiswa sebagai calon guru. Dengan pengembangan kegiatan praktikum yang lebih berorientasi pada pendekatan ilmiah diharapkan dapat mengembangkan keterampilan proses sains serta memberikan pengalaman kepada mahasiswa untuk berpikir lebih ilmiah dan menyelesaikan masalah yang dihadapi. Prilianti (2014) Disadari bahwa guru-guru perlu memperkuat kemampuannya dalam memfasilitasi siswa agar terlatih berpikir logis, sistematis, dan ilmiah. Tantangan ini memerlukan peningkatan keterampilan guru melaksanakan pembelajaran dengan menggunakan pendekatan ilmiah.

Untuk mengembangkan semua keterampilan proses sains dalam perkuliahan biologi tentu perlu dikembangkan pembelajaran yang sesuai dengan cara berpikir IPA. Sulistyowatin dan Wisudawati dan Sulistyowati (2013) cara berpikir IPA meliputi believe, curiosity, imagination, reasoning, self examination. Harapanya dengan pembelajaran yang dapat mengembangkan keterampilanketerampilan yang dibutuhkan pada abad 21. Bryce et al. (1990), melalui pembelajaran sains, dapat dikembangkan berbagai aspek proses sains yang meliputi keterampilan dasar (basic skill), keterampilan proses (process skill) dan keterampilan investigasi (investigative skill) sebagai keterampilan tertinggi. Keterampilan dasar mencakup: observational skill, recording skill, measurement skill, procedural skill, dan following instructions. Keterampilan proses meliputi: skill of inference) dan selection of procedures. Sementara keterampilan investigasi berupa keterampilan merencanakan dan melaksanakan serta melaporkan hasil investigasi.

Selain harus mengembangkan pembelajaran yang berorientasi pada pendekatan ilmiah harusnya juga pembelajaran yang 
berorientasi penggunaan fasilitas ICT. Hasil observasi pada kegiatan praktikum juga ditemukan bahwa mahasiswa hanya menggunakan powerpoint untuk mempresentasikan hasil kegiatan praktikum. Padahal fasilitas kampus dapat mendukung tidak sekedar hanya fasilitas LCD untuk penggunaan ICT, kampus memiliki fasilitas wifi yang bagus dan ini menjadi potensi untuk mengembangkan pembelajaran secara online. Resti (2013) Penggunaan teknologi dalam pembelajaran biologi diwujudkan dalam multimedia untuk mendukung komplemen pembelajaran tatap muka dengan E-learning atau yang disebut blended learning. Adanya penggabungan pembelajaran berbasis teknologi internet ini erat hubungannya dengan perwujudan persepsi visual dan saraf untuk siswa dengan karakteristik belajar yang berbeda. Karakter belajar siswa yang berbeda-beda dapat difasilitasi dengan penggunaan multimedia yang memberikan manfaat dalam mengembangkan motivasi belajar siswa.

\section{KESIMPULAN}

Keterampilan proses sains yang muncul pada praktikum morfologi tumbuhan adalah mengamati, mengkomunikasi data, dan mengajukan pertanyaan.

\section{SARAN}

Perlu dikembangkan kegiatan praktikum yang lebih berorientasi pada pembelajaran dengan pendekatan ilmiah serta memanfaatkan fasilitas ICT sehingga lebih bisa memberikan pengalaman pembelajaran yang sesuai dengan kebutuhan abad 21.

\section{DAFTAR RUJUKAN}

Bryce, T.G.K, McCall, J, MacGregor, J, Robertson, I.J, dan Weston, R.A.J. 1990. Techniques for Assessing Process Skills in Practical Science. Teacher's Guide. Heinemann Educational Books Ltd., Oxford-London.

Dimyati dan Mujdiono. 2002. Belajar dan Pembelajaran. Jakarta: Rineka Cipta.

Donna M. Wolfinger. (1994). Science and Mathematics In Early Childhood Education. New York: Harper Collins College Publisher

Herawan, Dedi. 2007. Peranan Supervisi Akademik. Jurnal Pendidikan dan Kebudayaan Edisi Khusus II Tahun Ke-13.

Prilianti, R. 2014. Ketrampilan Proses Sebagai Penerapan Pendekatan Scientific Dalam Pembelajaran IPA . http://bdksemarang.kemenag.g o.id.

Resti. Vica Dian Aprelia. 2013. Kajian Neurosains Dalam Perkembangan Pembelajaran Biologi Abad 21. Seminar Nasional X Pendidikan Biologi FKIP UNS. http://www.jurnal.fkip.uns.ac.i d/index.php

Rustaman, Y. Nuryani. 2005. Strategi Belajar Mengajar Biologi. Malang: UN PRESS.

Toharudin U., Hendrawati S., dan Rustaman A. 2014 Membangun Literasi Sains Peserta Didik. Humaniora: Bandung

Usman Samatowa (2006). Bagaimana Membelajarkan IPA di Sekolah Dasar. Jakarta: Depdiknas Dikjen Pendidikan Tinggi Direktorat Ketenagaan 
Wilujeng, Insih. 2012. Redesain kurikulum $s_{1}$ pendidikan ipa menuju Standards for secondary science teacher preparation. Prosiding Seminar Nasional ISPI, 2012. academia.edu

Wisudawati Asih W dan Sulistyowati Eka. 2014. Metodologi Pembelajaran IPA. Bumi Aksara: Jakarta 